\title{
SOCIAL HEALTH INSURANCE AND ITS FAILURES IN THE CZECH REPUBLIC AND SLOVAKIA: THE ROLE OF THE STATE
}

\author{
Jozef MEDVEĎ, Juraj NEMEC, ${ }^{*}$ Leoš VÍTEK ${ }^{* *}$
}

\begin{abstract}
:
Health care reforms in the Czech Republic and in Slovakia are based on the implementation of market-based instruments into the system, namely on privatization and health insurance. Such changes, especially the change of the system of financing of health care from "socialist" taxation-based system to "modern" insurance-based one, were supported by many arguments, showing expected positive outcomes. However, after more than ten years from starting the change, health care system performance criteria in both countries have not been improved as expected. In our paper we try to examine some potential purposes of such trends, with focus on rhetoric and reality of potential of health insurance to improve the performance of health systems in transitional countries.
\end{abstract}

Keywords: health reform, health insurance, performance of health care system, Czech Republic, Slovakia

JEL Classification: I11, I18

\section{Introduction}

This paper focuses on problems connected with the introduction and management of new health insurance systems in the Czech Republic and in Slovakia, caused on a large scale by a lack of policy-making and policy implementation capacities of the state.

The first part briefly describes the history of health reforms in the Czech Republic and Slovak Republic after 1989. Both countries decided to switch from general taxation-based system of health care financing to insurance-based system. The second part presents basic indicators of resulting outcomes. It is apparent that such

*) Matej Bel University, Faculty of Finance, Cesta na amifiteáter 1, SK - 97401 Banská Bystrica (e-mail: jozef.medved@umb.sk; juraj.nemec@umb.sk). mfcr.cz).

${ }^{\star *}$ ) Ministry of Finance of the Czech Republic, Letenská 15, CZ - 11810 Prague 1 (e-mail: leos.vitek@

***) The Grant Agency of the Czech Republic supports this research (GAČR No. 402/02/P124). The views expressed in this paper are those of the authors and do not represent those of the Ministry of Finance or Matej Bel University. 
outcomes are not satisfactory, at least in the short term, and finance related, perspective. In the third part of the paper there is reviewed the main economic theory concerning the system of health care services financing in the country, with focus on main arguments supporting the use of insurance-based system, and their brief critical economic evaluation. The last part tries to find some potential answers, why the newly established insurance systems in both countries failed to serve as the effective regulator of health care quantitative and also qualitative aspects. It becomes obvious that the state in both countries, but probably on different scale, failed as the effective regulator of health insurance market, and its inconsistent, ad hoc interventions into the system just worsened situation.

\section{Health Reforms in the Czech Republic and in S I ov a k a}

At the beginning it is worth noting that with respect of political situation the starting condition of the Czech and Slovak reality were significantly different after 1989 (in spite of being in one state till the end of 1992). The fiction of the distribution of power under the communist federative state was its devolution to the republican level. After 1989 this formal constitutional provision became a political reality in health and in other policy areas as the politicians of both republics were able to pursue separate policies.

\section{1 Starting Conditions}

Our argument is that the health care policies and experiences under communism had the major determining influence on the problems of the two successor systems in the first decade of transition. The influence of the legacy of communism and planning, initially all pervasive, has now decreased. But it can still be seen in the relatively low priority given to health in state budgets, in low payments amongst health workers, in the supply-constrained nature of many of the services, and most obviously in the dominant role of the state, directly or indirectly, in determining supply, finance, incentives and new directions in provision.

The aim of the old system was to provide a comprehensive system of health care for all members of the society. All decisions on medical provision were made by the federal government and the national Czech and Slovak Ministries of Health. They were generally made on political or administrative grounds, and the only accountability was to the communist party. The important reason for the relatively low priority of health was a legacy of Marxist-Leninist political economy. Drawing on Marx's distinction between productive and unproductive labour, the official ideology placed health in the second and less prestigious ideological category. This reinforced its position as a non-key sector, and made its problems less urgent for policymakers. It also accounted for its relatively low wages, and its overwhelmingly female labour force.

A second aspect of the planned economy that was to shape the structural aspects of post-revolutionary Czechoslovak health care was the supply-constrained nature of the system. This had a damaging effect on quality, raising the importance of quantity above quality in plans, and led to producers being insensitive to consumers' wishes. Neither demand nor supply influences necessarily affected the output plans of institutions, and where exchange occurred it was the suppliers who dominated.

Concerning health the services were free at point of use, but only after 1987 did patients have the right to choose their primary care providers, opticians and dentists. There were no economic incentives to improve systemic performance, and in 
general excess demand prevailed. There were no attempts to reduce excess supplies or demands through either coordinated treatment scheduling, or pooling the resources of the different sectors of the health care system. Resources for health continued to grow, though at very modest rates, and in 1989 they presented roughly $5 \%$ of gross domestic product (GDP), against an OECD average of about $8 \%$.

In this starting situation, in many aspects better than in other post-Soviet countries, both Czech and Slovak governments started massive reforms, focusing on maintaining the access, increasing the quality, improving outcomes, especially life expectancy, and controlling the costs of health care systems. The Slovak government statement might be used as representative expression of main goals: „Government activities in the field of health care shall be based on the urgent requirements to stop the impairment of the state of health of the population. Based on the 'health for all' principle, the essential element in our policy of public health is to afford health care for every citizen of our republic as required by his state of health, financially based on the principle of mandatory health insurance, with the state providing this obligation in the case of economically inactive citizens. The insurance system shall result in radical changes not only in the health care financing field but will positively influence the physician - patient relationship" (Programme Declaration of the Government of the Slovak Republic, 1992).

\section{2 Health Care Reforms in the Czech Republic}

The first health care reform document in the Czech Republic was approved in 1990. The Working Group drafted it for reform representing large part of health professionals' communities, mainly physicians, academics, economists. The new system, based on principles of transparency, economization, democratization, humanization and higher standards of a quality of care brought in especially radical changes in organizational and institutional structure, funding, and reimbursement methods, following by abolishing existing system of organization of health care delivery in 1990 and 1991. All medical establishments became independent legal persons. Much earlier than in Slovakia basic rules for privatization of health providers were prepared, and since 1992 the private sector has started to exist. Within a few years most health establishments, except for larger hospitals, were privatized. As the for profit private sector indicates its interest (2004 trend) to purchase and operate also hospitals, it might be expected that only few large (academic) hospitals may remain in the hands of the Czech state by middle of the first decade of this century.

The Czech heath insurance system was created in 1992, one year earlier than in Slovakia. All changes were based on assumption that competition, mainly competition among insurance companies and among private providers will support positive developments - with this the Czech Republic applied more liberal approach to the economic aspects of the reform. However, a lot of complications and inefficiencies appeared as the result of overestimation of the effective impact of market forces in health care.

A separation of payers and providers of care was quite an important part of the reform. The new subject in the system was established - Health Insurance Companies (HICs). A contractual model has replaced an integrated one. Existing institutions (the so-called Institutes of National Health) were transformed into a network of independent, relatively autonomous health care facilities that became regular legal entities making decisions in their own name. There were only about 430 health care facilities in 1991, more than 22 thousand existed in the year 1995 (a physician's private practice was considered to be an independent health care facility). New nonstate and private facilities were founded. State institutions were transferred to muni- 
cipalities, some hospitals were privatized, and most of out-patient care was privatized too.

The transformation from national health service model, funded from the government budget, into the system of compulsory, universal public health insurance was probably the most important part of the reform. The whole system was designed as a multiple payer one. HICs are non-for-profit, public law, self-administered entities. A special legislation (adopted in 1991-1992) regulates strictly their functioning. HICs are open - there is a free choice of insurer for the citizens. Health care is funded from several sources, the main one is generated by public insurance premiums collected by HICs. Employees, employers, and the government pay insurance premium, and its amount is based on a gross income. Out-of-pocket payments creates less than $10 \%$ of total expenditures (spent mainly on drugs), public budgets have played more important role here.

\section{3 Health Care Reforms in Slovakia}

In spite of non-existence of formal link between health care reforms in Slovakia and the Czech Republic, most of processes and their results were relatively similar, usually realized with several months delay.

General trends of health policy in Slovakia were defined by Programme Declaration of Government and main reform documents (first of them published in 1990). The most important goals of the reform were health care for everybody, guarantee of "needed" scope of health care to everybody, cancellation of a state monopoly in health care, plurality of provision of health care, privatization, increased participation of self-government in health care system, introduction of comprehensive compulsory (social) health insurance, multi-resource financing of health care, and the effort to stop an impairment of health status of citizens. These goals did not change during the entire period, but in the later phase (after 1995), health finance and necessity to balance costs and resources became an increasing priority.

Slight changes of Slovak health policies after $2002^{1)}$ towards higher participation of patients might be well characterized by the Prime Minister Dzurinda's coalition government proclamation as follows: "The government focuses to stop increasing the debt of the system, and balance its economy, on the basis of equal financial contribution (in real terms) from the state budget as in 2002. The access and flexibility of services delivered shall increase; the priority for the state will be expensive treatments that cannot be paid individually by the patient. The preventive aspects of the system, a shift to ambulatory care, home care, and same day surgery shall be priorities. The law on health care shall define the scope of services financed via compulsory insurance; all other services shall be paid from voluntary insurance system" (Sme, November 5, 2002, p. 2).

Two most important reform dimensions were the development of the insurance system and privatization. Slovakia introduced a system of social health insurance to replace the old general taxation system of finance. The main laws regulating health insurance were passed in 1994, laying the foundation for establishing thirteen

1) In June 2004 the health minister Zajac prepared and submitted to the Parliament a set of new health laws, expected significantly to change the system, by increasing the level of co-payments, introducing commercial voluntary health insurance, and changing health insurance companies into joint-stock companies. All these six draft laws are currently in the legislative process. 
health insurance companies. Most of these disappeared from the "market" leaving only five by 2002 .

The privatization of the Slovak health care system started in the middle of the 1990s mainly in out-patient care and pharmacies. The objective of privatizing inpatient care was proclaimed several times, but by 2001 there were only three nonstate hospitals in the whole country. In 2002 the management of hospitals was decentralized, and some hospitals were given self-governing status. Only in $2003-$ 2004 period some hospitals became non-profit semi-independent bodies.

In primary care, in 1995 the state system accounted for $58 \%$ of expenditures, in 1996 only for $8 \%$, and by 2001 for $5 \%$. For pharmacies, the development was similar - the proportion in the state sector decreased from $97 \%$ in 1995 to $5 \%$ in 1996 and $3 \%$ in 2001 . The privatization of specialized ambulatory care was slower, but by 2001 the state sector accounted only for $26 \%$ of facilities (see Zajac, Pažitný, 2002).

\section{Selected Outcomes of Health Reforms in the Czech Republic and Slovakia}

It is difficult to assess the outcomes and the impact of any reform measure, especially in areas where non-financial costs and benefits dominate, as in health care. To cope with this, several international organizations have tried to introduce their own evaluation systems focusing on different aspects and using different methods. For the purpose of this paper we selected the following:

- health status of inhabitants,

- access to care,

- clinical quality of care and satisfaction (clients, quality of care) for process and for results (quality of care),

- efficiency and economy of care.

\section{1 Health Status of Inhabitants}

One of main indicators of health status, the life expectancy in both countries and for both sexes, has continued to grow (see Table 1). Infant mortality is lower, so is the new-born mortality rate. However, there was an increase in low birth weight babies, from $5.6 \%$ to $6.5 \%$, between 1989 and 1995 (see UNICEF, 1997). The reason for this last phenomenon is probably the rise of unemployment, which has hit the high birth rate of Roma population particularly hard. The reasons behind the improved mortality statistics are likely to be an increase in health spending as a proportion of GDP, and a lower rate of pollution-related deaths, as many of the worst industrial polluters were closed or shrank in response to falling demand.

Table 1 indicates significant improvement in health indicators in both republics during the first seven years of the post 1989 reform period. The improvement rate for the Czech Republic is, however, the higher of the two and an interesting question is whether this may be related to that republics greater privatization of health facilities, or to its relatively greater spending on health. This is a difficult question to answer convincingly, given the very limited nature of the available statistical evidence. Our subjective assessment is that the Czech experience has more to do with resources than ownership. If we examine the degree of privatization, and the relative efficiency of the private and public sectors, this assessment is the most plausible conclusion. 
Table 1

Selected Health Outcomes, Czech Republic (CR) and Slovak Republic (SR)

\begin{tabular}{|l|l|c|c|c|c|c|c|}
\hline \multicolumn{2}{|c|}{} & 1985 & 1990 & 1995 & 2000 & 2001 & 2002 \\
\hline \multirow{3}{*}{$\begin{array}{l}\text { Life expectancy (for } \\
\text { live births = age 0) }\end{array}$} & CR men & 67.5 & 67.5 & 70.0 & 71.6 & 72.1 & 72.1 \\
\cline { 2 - 8 } & SR men & 66.9 & 66.6 & 68.4 & 69.1 & 69.5 & 69.8 \\
\cline { 2 - 8 } & CR women & 74.7 & 76.1 & 76.9 & 78.4 & 78.4 & 78.5 \\
\cline { 2 - 8 } & SR women & 74.7 & 75.1 & 76.3 & 77.2 & 77.5 & 77.6 \\
\hline \multirow{2}{*}{ Death per 1000 alive } & CR & 12.7 & 12.5 & 11.7 & 11.0 & 10.8 & 11.0 \\
\cline { 2 - 8 } & SR & 10.2 & 10.2 & 9.8 & 8.6 & 9.7 & 9.6 \\
\hline \multirow{2}{*}{$\begin{array}{l}\text { Infant mortality per } \\
1,000 \text { live births }\end{array}$} & CR & 12.5 & 10.8 & 7.7 & 4.1 & 4.0 & 4.0 \\
\cline { 2 - 8 } & SR & 16.3 & 12.0 & 11.0 & 8.6 & 6.2 & 7.6 \\
\hline
\end{tabular}

Source: Statistical Office of the Slovak Republic, 2003; Czech Statistical Office, 2003; Lawson, Nemec, 2003.

\section{2 Access to Health Care}

Both systems are still based on a widespread and popular commitment to universal access to health care, free at the point of use. There is a comprehensive legal basis to such access in both republics and it is the electorate's preferences that sustain these laws and regulations that mark the limits to organizational and operational change. The differences between the countries lie mainly in the formal way the access to health care is guaranteed. Both constitutions provide that everyone has the right to health protection. While many of the Czech access conditions and rights are set out in government regulations, in Slovakia they are more commonly incorporated into formal laws. ${ }^{2)}$

To give a single example of how general political promises of universal access are made concrete, the Slovak Act on Health Care declares: "...everybody has the right to get health care, including medicines and medical aids. Health care is provided by state health establishments, municipal providers and other suppliers run by legal or physical entities, and is provided on the basis of current medical and scientific knowledge. Health care is provided for citizens (i) free of charge, on the basis of compulsory health insurance, (ii) on the basis of supplementary insurance contracts, (iii) free from the state budget, (iv) on the basis of the financial resources of charities, legal or physical entities or ( $v$ ) is based on co-payments or the full payment by the recipient of the care."

While access may in law be free of charge, corruption ensures that access is not equal. There are no effective Patients' Charters, and complaints generally find no responsive addressee. This is important because more than two-thirds of Slovaks and perhaps one-third of Czechs claim that they have had to bribe someone to ensure good care. In the latter case bribes have been estimated to amount of a tenth of

2) For example the four most important documents are Act No. 272/1994 on Health Protection; Act No. 277/1994 on Health Care; Act No. 98/1995 on Treatment Regimes and Act No. 273/1994 on Health Insurance. 
health costs. Unless there is a sea change in government law enforcement then a complaint to the new Czech ombudsman's office is a patient's best hope.

Overall there is no evidence that in either country any group or citizen has been denied access to any free service they have a right to receive. Indeed in the Czech Republic the health legislation was amended in 1998 to forbid care providers from charging any fee for a service that is related to medically approved care. General practitioners, dentists and opticians cannot refuse to treat patients. But where unofficial waiting lists exist for specialists, because there are no formal and effective precedence rules for access, unequal treatment may occur. And with hospital care it is common to make additional illegal payments for extra services, for example, for a separate room. A systematization of these practices through additional co-insurance is likely to be introduced, at least in Slovakia, where the respective legislation is already in Parliament (on the other hand, new proposed legislation in Slovakia may decrease the level of access for some groups by introducing comprehensive scale of co-payments).

The World Health Organization (WHO) recognized the existence of certain gaps in access to health care services in both republics too. Its World Health Report 2000 (see WHO, 2001) ranks the Czech Republic only on the $71^{\text {st }}$ and Slovakia on the $96^{\text {th }}$ place in the world, concerning the level of fairness in the heath system and the value of this indicator is dominantly based on universality of access (see Table 2). WHO in its report evaluated health care systems in the word according to three criteria health of the nation (health status), fairness of the system (mainly universality and equality in access) and costs. There is no doubt that first two criteria represent positive aspects of the system (in spite of the fact that health status is expected to be influenced by health care by maximum $20 \%$ ), however, the level of costs must not always be just positive indicator (significantly higher costs in U.S. do not represent significantly better care).

Table 2

Ranking of Health Care Systems: Selected Countries ${ }^{1)}$

\begin{tabular}{|l|c|c|c|c|}
\hline & Overall & Health & Fairness & Cost $^{2)}$ \\
\hline France & 1 & 4 & 26 & 4 \\
\hline United Kingdom & 18 & 24 & 8 & 26 \\
\hline Germany & 25 & 41 & 6 & 3 \\
\hline USA & 37 & 72 & 54 & 1 \\
\hline Slovenia & 38 & 62 & 82 & 29 \\
\hline Czech Republic & 48 & 81 & 71 & 40 \\
\hline Poland & 50 & 89 & 150 & 58 \\
\hline Slovakia & 62 & 88 & 96 & 45 \\
\hline Hungary & 66 & 105 & 105 & 59 \\
\hline Estonia & 77 & 115 & 145 & 60 \\
\hline Russia & 130 & 127 & 185 & 75 \\
\hline
\end{tabular}

1) Based on 1997 data for 191 countries. Highest level $=1$.

2) Based on total spending per head (in USD).

Source: World Health Organization, 2001. 
Despite the chronic and sometimes acute funding crises there were more resources available to treat illnesses. For example, the director of one of Prague's more specialist hospitals, Na Homolce, stated that, "Back in 1990, only people aged under sixty could get kidney dialysis. Now it's available to everyone. And we do six times as many heart bypass operation as we did then" (Business Central Europe, March 2001, p. 46).

Finally it is worth noting the re-emergence in 2001 of special treatment facilities for senior Slovak government officials, after the failure in 2000 to treat the President's life-threatening condition required his removal to Austria for treatment. This policy change recognizes the lack of advanced health care facilities in Slovakia, and is the first formal post-communist expression of inequality in the system. The elite calculated, apparently correctly, that the electorate's patriotic sentiment would outweigh any resentment at the creation of two levels of service.

\section{3 Clinical Quality of Care and Satisfaction (Clients, Quality of Care) for Process and for Results}

It is very difficult to assess developments in the quality of care in both republics after 1989, as there are no available indicators. As already noted, there have been significant quality improvements on the supply side. These have been mainly in the structure and quality of equipment available in health establishments, and in the range of medicines available and used for treatment.

After 1989 several barriers limiting the possibility of importing top "Western" technologies were dismantled, and the regulations concerning what can be purchased and prescribed were weakened. Such trends delivered contradictory outcomes - on the one hand, there were improvements in the technical aspects of quality of services, on the other hand, there was a relative "oversupply" of technologies and expensive drugs, which was one of the causes of financial problems in the system.

Compared to positive technical developments, the trends in other aspects of health care quality are more controversial, however, difficult to prove. In spite of many promises no Czech or Slovak government was able to introduce systematic medical and organizational audit of health providers, which would tell us more about how the care is delivered.

In Slovakia only in October 2002 with the appointment of a new health minister, the government has been willing to accept that problems with the medical quality of care exist and probably increase year by year, as the consequence of the persistence of many unsolved internal problems in the system (for example not only low, demotivating wages for personnel, but also the non-existence of required technical clinical standards). The case of the mistreatment of the Slovak President in 2000 (see Zajac, Pažitný, 2000) clearly showed basic weaknesses in the daily delivery of care, but it was not used as an impetus for changes.

Compared to the Czech Republic, where almost nothing changes to protect clinical quality of health care, the Slovak Ministry of Health initiated several actions to improve the situation, like creation of special unit for patients' complaints at the Ministry, promise to introduce medical standards for all levels of health care, also known cases of mistreatment are immediately inspected by the Ministry. In most such cases responsible doctors were suspended, even respective hospital department temporarily closed.

The organizational (patient's) quality of care improves, but very slowly. Compared to the old system, there is a choice of provider, but the patient is still very far from becoming the central subject of the system. The situation is slightly better in the Czech Republic, it may be the positive outcome resulting from faster privatizati- 
on. In Slovakia the document "Patient Rights" was prepared and published in 2000, and some establishments have not yet adapted it fully to local conditions. Queuing for treatment without the option for a precisely appointment is typical with most providers, including private ones.

\section{4 Efficiency and Economy of Care}

Taken together the governmental statements identify as one of the main aims of transition an improving efficiency. But in practice such aim has not been consistently realized; and by 2002 both the Czech and Slovak systems, and especially the hospital and insurance sectors (in Slovakia), were heavily indebted. In addition several crucial and chronic weaknesses remained. Specifically: low economic efficiency; a lack of evidence-based decisions; low relative pay and the attendant labour retention problems; too large drugs bills and insufficiently effective management of capital programmes, and a general underdevelopment of preventive medicine. Shortage of funds led hospitals to proliferate the range of services, and to pay low wages. Drug bills exploded, rising from one percent of GDP in 1991 to almost two per cent in 1996 in both countries (see Kuvíková et al., 1998). The lack of overall control of the system led to inefficient capital investment programmes, and insufficient resources were devoted to preventive medicine (see Malý, 1998).

The Tables 3 and 4 provide basic data characterizing the financial situation of health care systems in the Czech Republic and in Slovakia.

Table 3

The Economic Performance of the Health Care System in Slovakia (in SKK bill.)

\begin{tabular}{|l|r|r|r|r|r|r|c|}
\hline & 1996 & 1997 & 1998 & 1999 & 2000 & 2001 & 2002 \\
\hline Health insurance system resources & 35.4 & 38.4 & 41.4 & 43.0 & 45.3 & 49.6 & 55.0 \\
\hline Resources from the Ministry of Health & 4.6 & 4.9 & 4.7 & 4.4 & 4.5 & 4.9 & 4.8 \\
\hline $\begin{array}{l}\text { Resources from Social Insurance } \\
\text { Company }\end{array}$ & 1.0 & 1.2 & 1.3 & 1.3 & 1.0 & 1.1 & 1.2 \\
\hline Direct payments from inhabitants & 2.6 & 3.8 & 4.1 & 5.4 & 5.9 & 6.3 & 7.0 \\
\hline Total resources & 43.6 & 48.3 & 51.5 & $\mathbf{5 4 . 1}$ & $\mathbf{5 6 . 7}$ & $\mathbf{6 1 . 9}$ & $\mathbf{6 8 . 0}$ \\
\hline Primary care costs & 4.3 & 4.5 & 4.2 & 4.4 & 4.7 & 4.9 & 5.1 \\
\hline Secondary ambulatory care costs & 0.2 & 1.3 & 1.5 & 1.8 & 1.9 & 2.1 & 2.2 \\
\hline In-patient care costs & 21.4 & 24.0 & 25.6 & 25.0 & 26.0 & 28.1 & 29.5 \\
\hline Medicaments and health aids costs & 12.2 & 14.5 & 16.1 & 18.8 & 20.6 & 22.8 & 24.1 \\
\hline Other costs & 1.1 & 3.4 & 5.0 & 4.1 & 6.9 & 7.7 & 8.0 \\
\hline Ministry of Health costs & 4.6 & 4.9 & 4.7 & 4.4 & 4.5 & 4.9 & 4.8 \\
\hline Total costs & 43.8 & $\mathbf{5 2 . 5}$ & $\mathbf{5 7 . 1}$ & $\mathbf{5 8 . 5}$ & $\mathbf{6 4 . 6}$ & $\mathbf{7 0 . 5}$ & $\mathbf{7 3 . 7}$ \\
\hline Balance & -0.2 & -4.2 & -5.6 & -4.4 & -7.9 & -8.6 & -5.7 \\
\hline Deficit coverage & 0.2 & 4.2 & 5.6 & 4.4 & 7.9 & 8.6 & 5.7 \\
\hline External debt & 0.2 & 4.2 & 5.6 & 4.4 & 4.4 & 5.2 & 2.1 \\
\hline Privatization grants & 0.0 & 0.0 & 0.0 & 0.0 & 3.5 & 3.4 & 3.6 \\
\hline
\end{tabular}

Source: Nemec, Ginter, 2003. 
Table 4

The Economic Performance of the Health Care System in the Czech Republic (in CZK bill.)

\begin{tabular}{|c|c|c|c|c|c|c|c|}
\hline & 1996 & 1997 & 1998 & 1999 & 2000 & 2001 & 2002 \\
\hline $\begin{array}{l}\text { Health insurance system } \\
\text { resources }\end{array}$ & 89.1 & 97.5 & 107.9 & 110.5 & 115.9 & 131.1 & 137.5 \\
\hline $\begin{array}{l}\text { Resources from the central } \\
\text { and local governments }{ }^{11}\end{array}$ & 12.6 & 11.5 & 11.8 & 13.1 & 13.7 & 14.0 & 16.7 \\
\hline $\begin{array}{l}\text { Direct payments from } \\
\text { inhabitants }\end{array}$ & 8.3 & 9.9 & 10.6 & 11.5 & 12.2 & 13.7 & 14.5 \\
\hline Total resources & 110.0 & 118.9 & 130.3 & 135.1 & 141.8 & 158.8 & 168.7 \\
\hline \multicolumn{8}{|l|}{$\begin{array}{l}\text { Health insurance companies } \\
\text { costs: }\end{array}$} \\
\hline Primary care costs & \multirow{2}{*}{20.1} & \multirow{2}{*}{17.3} & \multirow{2}{*}{17.4} & 5.6 & 5.8 & 6.4 & 6.7 \\
\hline $\begin{array}{l}\text { Secondary ambulatory } \\
\text { care costs }\end{array}$ & & & & 12.6 & 12.9 & 14.1 & 15.9 \\
\hline In-patient care costs & 30.3 & 42.6 & 46.2 & 50.7 & 52.5 & 58.2 & 66.0 \\
\hline $\begin{array}{l}\text { Medicaments and health } \\
\text { aids costs }\end{array}$ & 20.4 & 20.6 & 21.9 & 27.1 & 27.4 & 29.5 & 32.6 \\
\hline Other costs & 9.5 & 10.1 & 10.9 & 11.8 & 12.5 & 13.3 & 14.5 \\
\hline $\begin{array}{l}\text { Costs of the central and local } \\
\text { governments }{ }^{1)}\end{array}$ & 12.6 & 11.5 & 11.8 & 13.1 & 13.7 & 14.0 & 16.7 \\
\hline $\begin{array}{l}\text { Difference between revenues } \\
\text { and costs of the health } \\
\text { insurance system }\end{array}$ & -2.5 & -0.9 & -1.1 & 2.5 & 2.1 & 1.4 & -1.2 \\
\hline Net income of hospitals & n.a. & -1.0 & -0.3 & -1.1 & -0.9 & -1.0 & -1.6 \\
\hline
\end{tabular}

1) The Table 4 does not include data from other central government branches then Ministry of Health. These resources aggregate at approx. CZK $2.0-2.5$ bill. per year (in $1998-2002$ ). Other and total costs of health care system are not available.

Source: Czech Statistical Office, 2004; Institute of Health Information and Statistics of the Czech Republic, 2003 and 2004; Institute of Health Policy and Economics, 2004.

The under-financing of the systems at the beginning of the reforms after 1989 , and the decrease in GDP as the result of transition, represent objective factors lying behind the financial problems of the health care system. However, there are also significant subjective factors, mistaken reform design and implementation issues that brought the system close to collapse and are worth discussing.

The data show that in spite of the economic performance of the system and the necessity to improve the agenda of both governments, the real results are unsatisfactory. In Slovakia from 1997 the system systematically spent $10-15 \%$ more than the available resources and this trend did not change in spite of many attempts to rectify it. In the Czech Republic this trend appeared especially after 2000. The financial situation of both systems was critical in 2003. The Czech system is indebted on the level of $10-20 \%$ of yearly public health expenditures. The situation in Slovakia is even worse, above $50 \%$ of this figure. 


\section{Financing of Health Care: Main Economic As - pects}

There is more or less common agreement between all economic theories (maybe except for very specific one, like objectivism - see Kinkor, 1996) that health and health care cannot be just individual responsibility of citizen, and certain role of the state is inevitable. Even recent attempts to introduce more market into the system just confirmed that the capacity of health care system for market principles is limited. "While such reforms have been widely espoused in international fora as well as by technical experts, their implementation has been much more limited. It is difficult to assess the real potential for new public management reforms in the health sector because such reforms have been either partial or only recently introduced" (Bjorkman, 2004, pp. 12-13).

There are some basic economic and socio-economic arguments supporting state interventions into the health and health care system, based on allocative and redistributive roles of government (see Stiglitz, 1989). We can provide some highlights on this topic.

A perfectly competitive market with well-informed and rationally acting providers and consumers is a structural means by which an optimal allocation of resources may be obtained. However, there are several obstacles preventing the achievement of allocative efficiency in the health care market, mainly:

- health care is an impure public good,

- informational asymmetry,

- externalities,

- uncertainty and complexity.

In the case of health care the exclusion of consumers is technically possible, but socio-economic non-desirable. There is a general opinion (at least in developed Europe - see European Charter of Social Rights) that everyone is eligible for basic health care services independently of their ability to pay. Additional argument - especially in case of emergency the transaction costs to check the patients' ability to pay might be too high.

Most authors argue that the limited information on the side of the patient/consumer (see Cullis, 1979) is the most important obstacle preventing health care from the free market. The free market conditions implies that the consumer of health services must obtain information about the production relationships that govern the effectiveness of all available treatments and information concerning the likely future effects on their health status. In reality, the consumer has little or no information concerning their needs, level and form of treatment required, and the effectiveness of the treatment. Thus, the consumer has to rely on the producer for all information. Because of this information asymmetry and the character of "good - health care", for example Feldstein's (1993) demand model suggest that the most important factor limiting the individual demand for health services is ability to pay.

Health care is connected with several kinds of positive externalities and its provision as a public good can prevent some negative externalities. Very important positive externalities result, for example, from preventive measures, vaccination and supporting of technical development.

Each case in health care system is potentially different from every other case. It is impossible to suppose that two different persons with the same diagnosis will have the same treatment - methods, medicines, and length of recovery, reactions, and so forth. Because of this the supply of health care represents a complicated sequence of adaptive responses to conditions of uncertainty - uncertainty concerning the best way to treat the patient from the time the illness occurs. 
The socio-economic dimension of health and health care shall be also recognized. As highlighted in already mentioned example of WHO evaluation of health care systems in the world (see Table 2), universality of access is main health related value in all developed world.

Pros and Cons of Existing Systems to Finance Health Expenditures. In previous part main arguments for including of public finance into the system of health care delivery were provided, showing that health care system in any developed country represents some balance between private and public finance: "...the private sector for the delivery of health care in developing countries is already extensive. Indeed, the private sector is often bigger than the public sector - but, due to ideological blinkers or 'group think', the private sector has not been acknowledged and therefore not measured, at least in public data sets" (Bjorkman, 2004, p. 12).

The issue is optimal decision on how to bring public finance into the system. The world experience (see Alttensteter, Bjorkman, 1997) provide following main forms of public financing of health care services:

a) general taxation-based model (responsible for financing of dominant part of health services for example in United Kingdom, or Nordic countries, used as the norm in former socialist regime in Central and Eastern Europe),

b) social insurance-based model (frequently called Bismarckian model, where the state provides resources via insurance market),

c) program model of providing public funds for health care (typical example USA with MEDICARE, MEDICAID and several other programmes serving to improve access).

After 1989 the Czech Republic and Slovakia, similarly to more or less all postcommunist countries decided to switch from general taxation model of financing of health care to social insurance system. The change to a health insurance system was supported by typical arguments about plurality, independence and competition (see Lawson, Nemec, 2003), as the main positive features of new insurance-based system. For post-communist countries the political economy rationale for such switch from a tax-based to an insurance-based financial model is a mixture of economic, administrative and political considerations. The economic arguments involve a trade-off between on the one side the costs of a public monopoly, the previous system, whose efficiency might have been improved by an internal market. And on the other side the possibility of excessive administrative costs, if there were many competing insurance companies but few economies of scale. Alternatively there would be the general economic welfare problems of oligopolies if the market turned out to be dominated by a small number of large insurance companies.

The administrative arguments for the change were that the new insurance companies were to be separated from the main government administration, and that by themselves they would improve the quality of the administration.

The political considerations for proposing a switch are complex. On the one hand, earmarking taxes for health, and sub-contracting their administration to apparently independent insurance funds would seem to have the advantage of distancing government from a contentious area of public policy. After all, the interest groups we have noted so far, excepting insurance companies, are not very concerned where any extra resources for health will come from. Neither local nor indeed many central health care policymakers are concerned about such trade-offs. They will continue to push for increased expenditure regardless of the consequences for either taxation or expenditure on non-health items. Thus the switch to an earmarked insurance system would seem to have the advantage of reducing pressure on general budgets. 
The purposes for concrete decisions in conditions of transition are straightforward. However, the general health economics theory and experience from the history of health systems in the world do not favour the insurance-based system, but just show positives and negatives of any system, and conclude that there is no general prescription, and the decision shall be based on careful evaluation of local internal and external situation of the health system, similarly to any other public sector reform approach (see Coombes, Verheijen, 1997). As any other, the insurance system is not the only alternative, and it involves a lot of possible problems, even if introduced in an optimum way. We mention some of them.

Many authors argue that private health insurance would fail to cover high-risk groups of citizens (see Feldstein, 1993). Persons with high probability of needed high-cost treatments will usually pay a very high premium that might be over their ability to pay. Typical problem is "cream-skimming/cherry-picking" (see Cullis, 1979) - insurance companies try to select "best risk" customers, who are usually healthy and reach people. Insurance system has limited possibility to regulate allocative efficiency of health expenditures, and it is possible to prove that too high level of health care expenditures per capita does not bring any extra inputs into the level of health status of inhabitants. Insurance system is based on competition, but the level of competition in health care is naturally limited, as clearly shown, for example, by the experience from United Kingdom health reform in the nineties (see Klein, 1992).

\section{The State and Reform Failures}

From short evaluation of outcomes of health reforms in the Czech Republic and in Slovakia it is apparent that some aspects of the system are improving, mainly health status of inhabitants, and to some extend also quality of care, but the factors laying behind are probably on a large scale different from impacts of new health insurance system. On the other hand, the economic performance of both systems is really weak, and financial problems exaggerate, clearly showing that the health insurance system did not achieve its goals in this area. What are the main purposes?

The arguments might be found both in external and internal health insurance environment. From political point of view, certain important factors limited the chance for successful reforms. From 1989 till 1998 Slovak governments have been mainly unstable and generally short-lived coalitions. And in a world of drastic economic and political change it is unsurprising that only a minority of the Slovak electorate has shown some taste for significant social change. In late 1994 the Focus Polling Agency recorded that at the point of independence in late 1992, while 41 per cent of respondents thought that "radical changes of society" were necessary, $46 \%$ thought that only "small changes" would suffice (see For People and..., 1995). In the Czech case the medical profession was a most important pressure group. Since 1990 all Czech health ministers have been doctors, and from the start the doctors' trade union, the Czech Medical Association has been a very active player in the process of constructing reform plans. Radičová and Potůček (1997) go as far as arguing that health care professionals have in effect "captured" the Health Ministry to promote their interests.

From economic point of view, as mentioned more times, both republics have to cope with important problem - problem of discrepancy between "needs" and resources. Both systems heavily depend on public finance based resources, part of them coming via the health insurance system, and part of them directly from the state budget. The participation of patients in the form of direct payments/co-payment is still rather limited and much lower than in most developed countries. The total 
amount of resources is more or less directly limited by the performance of the national economy, which is much below the EU average (whether in nominal or purchasing power parity terms), and in terms of total output has only recently reached the level of the pre-transition period. On the other hand, all actors (doctors, politicians, patients, pharmaceutical companies), except for insurance companies (not able to control the market, as explained later), are interested in the increase of scope and scale of health services delivered.

Concerning internal environment, we already indicated that the change to a health insurance system was supported by typical arguments about plurality, independence and competition as main factors stimulating positive changes. However, none of these preconditions for insurance market to work was achieved.

\section{1 Plurality and Competition}

Both in Slovakia and the Czech Republic, the Parliaments lay down the level of insurance payments in relation to wages. The influence of the state on insurance companies does not stop at parliamentary finance votes. The Ministries of Finance and of Health determine most aspects of companies' payments, from the structure of the reimbursement system to the point values of all medical services, set maximum level of administrative costs. Furthermore, the Slovak Parliament also deliberately decides on the level of the state contribution for economic inactive citizen, representing important part of insurance funds.

In the Czech Republic there was initially no upper limit to reimbursements, and so its system was more liberal and less tightly controlled. In fact with flexible reimbursement limits and fee-for-service payments the Všeobecná zdravotní pojištovna (General Health Insurance Company), which began with $97 \%$ of the market in 1992 , was bankrupt within five months and had to be re-launched. After this, measures similar to Slovakia were introduced, however, insurance companies have more freedom to set the reimbursement rate (premiums are fixed).

The level of equalization between insurance companies was a matter of permanent fight between different actors in both republics, involving frequent changes of the system, but ending with $100 \%$ equalization in Slovakia already from 1999, the same is expected to happen in 2004 in the Czech Republic, significantly limiting space for competition.

The financial, especially reimbursement rules changed in both countries relatively frequently. The worthier example are Slovak rules for reimbursement of providers, changing almost every year (see Table 5).

The Czech system was not so instable, during the whole period $1993-1996$ the fee for service was used on all levels of the system, as provided by respective legislation (Act No. 550/1991). This system created large oversupply of services provided, and was not able to survive longer. As the reaction, in period $1997-2000$ more changes were introduced in a relatively short period (see Table 6).

The impacts of such tight regulation of freedom of insurance system are straightforward. In both countries the change saw a proliferation of companies followed by rapid consolidation. In both countries the markets came to be dominated by single players, the Czech General Health Insurance Company (CVZP) and the Slovak General Health Insurance Company (SVZP).

By late 1995 twelve insurance companies were operational in Slovakia, including the SVZP and separate companies covering the Ministry of Internal Affairs, the railways and the armed services, corresponding to their previously noted separate health care systems. Large companies set up their own schemes, though they encouraged non-employees to join, generally promising more benefits than the SVZP 
Table 5

Reimbursement Systems for Providers in Slovakia

\begin{tabular}{|c|c|c|c|}
\hline Date & Primary ambulatory care & $\begin{array}{l}\text { Secondary ambulatory } \\
\text { care }\end{array}$ & Hospitals \\
\hline 1. 1.1993 & Capitation & Fee for service & $\begin{array}{l}\text { Differentiated price per treatment } \\
\text { day }\end{array}$ \\
\hline 1. 4.1993 & Point system & Point system & Point system \\
\hline 1. 5.1994 & & & Lump sum \\
\hline 1.7. 1994 & & & $\begin{array}{l}\text { Differentiated price per treatment } \\
\text { day }\end{array}$ \\
\hline 1. 9.1994 & Capitation & & \\
\hline 1. 4. 1995 & Combined system & & \\
\hline 1. 4.1997 & & & $\begin{array}{l}\text { Differentiated price per treatment } \\
\text { day, change of basis }\end{array}$ \\
\hline 1. 12. 1998 & Capitation & & Budget \\
\hline 1. 1.1999 & & $\begin{array}{l}\text { Fee for service with } \\
\text { upper limit }\end{array}$ & \\
\hline 1. 5.1999 & & & Prospective budget \\
\hline 1. 6.2000 & Capitation based on age & & Maximum price \\
\hline 1. 1.2002 & $\begin{array}{l}\text { Capitation combined with } \\
\text { fee for service }\end{array}$ & & Service contracts \\
\hline
\end{tabular}

Source: Zajac, Pažitný, 2002.

Table 6

Changes in Reimbursement Systems for Providers in the Czech Republic since 1997

\begin{tabular}{|l|l|l|}
\hline Legislative norm & Valid from & Area concerned \\
\hline Act No. $48 / 1997$ & 1.4.1997 & Negotiations on frame contract, on list of services and on prices \\
\hline Act No. 2/1998 & 27.1.1998 & Negotiations on frame contract and on prices \\
\hline $\begin{array}{l}\text { Decision of the } \\
\text { Constitutional Court }\end{array}$ & 31.12 .2000 & Negotiations on prices \\
\hline Act No. 459/2000 & 31.12.2000 & Negotiations on prices \\
\hline
\end{tabular}

Source: Háva and Goulli, eds., 2003.

for the same basic insurance payment. Additional insurance was obtainable from the companies, which ended equality of treatment for the general population, and contributed to the low fairness ranking in Table 1. The same observation applies to the Czech Republic. However, the situation changed rapidly.

In Slovakia both government and economic pressures led to a fall in the number of competing companies. Basically the eleven non-general companies were cherry picking that is, segmenting the market. The SVZP ended up with $75 \%$ of the pati- 
ents, but with the least attractive ones from a medical and hence profitability standpoint. After several bail-outs, by early 2002 the system had been reduced to only five companies. To remove the impact of cherry picking, once the companies have collected their contributions all of the funds are pooled and redistributed according to the company clients, age and sex profile. In effect competition has been removed.

In the Czech Republic the number of companies peaked at 26 in 1994, but it had fallen to nine by 1999. Again after bail-outs and consolidations the cost containment performance of the companies improved. The CVZP also ended up with a dominant market share position, but with the least profitable $70 \%$ of clients. The government reacted by redistributing $60 \%$ of the total funds collected, removing a significant degree of competitive pressure.

The outcomes of such processes are straightforward - today the "health insurance market" has more or less monopolistic character in both countries, and because of this the potential of market mechanisms cannot be used.

\section{2 Independence}

Depending on the legislation covering the regulation of the companies, both insurance-based system multiplied politicians' possibilities for intervention. Such path was frequently chosen by the Slovak Parliament, which has repeatedly used its powers of intervention in an unwise manner. For example, under the Act No. 374/94 the Parliament determines the annual payments to the insurance system for the twothirds of the population who are either civil servants or are inactive. From 1995 the Parliament withheld significant amounts of those payments for no discernable good reasons, forcing the health care system to delay payments and waste resources in lobbying politicians for their release. By subsequent legislation the private sector lost any real legal chance to be repaid for "compulsory crediting" of health establishments, in the form of non-paid invoices for delivery of goods and services to health sector (see Table 4). In the Czech Republic the Parliament prohibited any delivery of health services for fee, even in the private sector.

Even today, neither Slovakia, nor the Czech Republic were able to introduce voluntary private health insurance schemes, still prohibited by the legislation, in spite of their important potential concerning costs and quality.

Taking into the account also facts provided in previous paragraph, we might claim that more or less zero level of independence of insurance system from the state was achieved, and by this other main precondition for market system was not achieved.

\section{Conclusion}

Both the Czech Republic and Slovakia replaced previous "socialist" taxation based system by new "modern" insurance-based system of health care system financing. This decision was not based on careful evaluation of internal and external environment, neither on pluses and minuses of insurance system, but represented "poor" political type of decision.

The outcomes of health reforms in both countries show some positive trends, mainly of indicators of health status of inhabitants and to some extend also in quality of care, however, it seems that this progress is dominantly caused by other factors than the insurance system. On the other hand, the insurance system clearly failed in its main role - increasing efficiency of health care delivery and improving of financial performance of the system. 
Data, provided by this paper clearly show that one of factors causing the (shortterm?) failure of new insurance systems in both countries is inappropriate behaviour of the state, acting in contradictory way, as follows:

- on the one hand introducing health insurance and certain other market type mechanism into the health care system, willing to use potential benefits of market based regulation in the area,

- on the other hand, limiting any scope for competition and independency by permanently intervening into the health insurance system, by frequently changing the rules.

The outcomes of such approach are straightforward (similarly to attempt to produce bananas on apple tree in Central Europe): blocking of any/most potentially positive impacts of insurance-based system of financing, and monopolizing the system, underlining it to the state by direct and indirect mechanisms. A lot of resources were devoted to introducing of health insurance system, but these resources, both in Slovakia and the Czech Republic, have been spent just to replace one type of the state monopoly in financing of health care by other type of the same system.

References

Altenstetter, C., Bjorkman, J. W. (1997), Health Policy Reform, National Variations and Globalization. London: Macmillan Press.

Auster, R. D. (1975), "Some Economic Determinants of the Characteristics of Public Workers," in Leiter, R., Sirkin, G., eds., Economics of Public Choice, Volume 2. New York: CUNY, pp. 185-198.

Bjorkman, J. W. (2004), "Health Sector Reforms - Measures, Muddles, and Mires," in Rosenbaum, A., Nemec, J., Tolo, K., eds., Health Care Delivery Systems: Opportunities for Public Management Education in CEE. Bratislava: NISPAcee, pp. 11-26.

Castle-Kanerova, M. (1992), "Social Policy in Czechoslovakia," in Deacon, D., ed., The New Eastern Europe: Social Policy Past, Present and Future. London: Sage, pp. 91-117.

Coombes, D., Verheijen, T. (1997), Public Management Reform: Comparative Experiences from East and West. Bratislava: European Commission.

Coulter, F., Heady, C., Lawson, C., Smith, S. (1997), "Social Security Reform for Economic Transition: The Case of the Czech Republic." Journal of Public Economics, 66, pp. 313-326.

CSO (2004), Statistical Yearbook of the Czech Republic 2003. Prague: Czech Statistical Office.

Cullis, J. G. (1979), The Economics of Health. London: Martin Robertson.

Davis, C. (2001), "The Health Sector: Illness, Medical Care and Mortality," in Granville, B., Oppenheimer, P., eds., Russia's Post-Communist Economy. Oxford: Oxford University Press, pp. 475-538.

Fallenbuchl, Z. M. (1991), "Economic Reform and Changes in the Welfare System in Poland," in Adam, J., ed., Economic Reforms and Welfare Systems in the USSR, Poland and Hungary. Basingstoke and London: Macmillan, pp. 110-131.

Feldstein, P. J. (1993), Health Care Economics. Albamy: Delmar Publishers.

For People and about People (in Slovak). Bratislava: SPACE.

Gedeon, P. (1995), "Hungary: Social Policy in Transition." East European Politics and Societies, 9 , pp. 433-458.

GSR (1992), Programme Declaration of the Government of the Slovak Republic (in Slovak). Document submitted for debate in the Slovak National Council, No. 2477/92/A. Bratislava: Government of the Slovak Republic.

(2002), Programme Declaration of the Government of the Slovak Republic (in Slovak). Bratislava, Government of the Slovak Republic. Sme, 5. 11. 2002, p. 2.

Háva, P., Goulli, R., eds. (2003), Health Finance from the Point of Reimbursement Systems (in Czech). Prague: Institute of Health Policy and Economics.

Háva, P., Kružík, L., Nemec, J., Mikundová, M. (1999), "Comparative Analysis of Czech and Slovak Health Policy after 1989", in Potůček, M., Radičová, I., eds., Social Policy in the Czech Republic and Slovakia after 1989 (in Czech). Prague: Charles University, pp. 289- 320.

Health Reforms Draft (1990) (in Czech). Prague: Czech Health Reform Group. 
Innes, A. (2001), Czechoslovakia: the Short Goodbye. New Haven and London: Yale University Press. IHISCR (2003), Czech Health Statistics Yearbook 2002. Prague: Institute of Health Information and Statistics of the Czech Republic.

(2004), Health Care and Health Statistics in the Czech Republic in Statistical Data 2003.

Prague: Institute of Health Information and Statistics of the Czech Republic.

IHPE (2004), Information about Public Health Insurance in the Czech Republic (in Czech). Prague: Institute of Health Policy and Economics.

Kinkor, J. (1996), Market and the State (in Czech). Prague: Svoboda.

Klein, R. (1992), "NHS Reforms." British Medical Journal, 25, pp. 36-51.

Kuvíková, H., Murgaš, M., Nemec, J. (1995), Health Economics (in Slovak). Banská Bystrica: Phoenix. (1998), Health Management (in Slovak). Banská Bystrica: Tri-

an.

Lawson, C., Nemec, J. (2003), "The Political Economy of Slovak and Czech Health Policy". International Political Science Review, 24, pp. 219-236.

Malý, I. (1998), Optimum Allocation of Health Resources (in Czech). Brno: Masaryk University. (2004), "Public Health Management and Policy Education and Training: Czech Republic," in

Rosenbaum, A., Nemec, J., Tolo, K., eds., Health Care Delivery Systems: Opportunities for Public Management Education in CEE. Bratislava: NISPAcee, pp. 121-141.

Miller, W. L., Grodeland, A. B., Koschechkina, T. Y. (1998), Are the People Victims or Accomplices? Budapest: LGI.

Nemec, J., Ginter, E. (2003), "Health Care", in Slovakia 2003 (in Slovak). Bratislava, Institute for Public Affairs.

OECD (1996), Economic Survey: Poland 1997. Paris: OECD.

Orenstein, M. (1995), "Transitional Social Policy in the Czech Republic and Poland." Sociological Review, 3, pp. 179-196.

Orviská, M. et al. (1997), "Public Sector Economics and Finance" (in Slovak). Banská Bystrica: Matej Bel University.

Pažitný, P., Zajac, R. (2001), Health Care Reforms Strategy (in Slovak). Bratislava: M.E.S.A. 10. "Picking Priorities: A Survey of Healthcare". Business Central Europe, March 2001, pp. 45-52.

Potůček, M. (1994), "The Transformation of Czech Health in 1990-1992." Prague, Institute of Sociological Studies, Charles University, mimeo.

Radičová, I., Potůček, M. (1997), "Two Social Policies Out of One: The Czech and Slovak Example." 19th meeting of the International Sociological Association Research Committee on Welfare State Challenge, Marginalization and Poverty. Copenhagen.

SOSR (2003), Statistical Yearbook of the Slovak Republic 2003. Bratislava: Statistical Office of the Slovak Republic.

Stiglitz, J. E. (1989), Economics of the Public Sector. New York: Norton.

Šumpíková, M. (2003), Public Sector Theory and Practice (in Czech). Prague: Megaprint.

UNICEF (1997), "Children at Risk in Central and Eastern Europe." Geneva, Regional Monitoring Report No. 4.

WHO (2001), World Health Report 2000. Copenhagen: World Health Organization.

Zajac, R., Pažitný, P. (2000), "Health Care”, in Slovakia 2000 (in Slovak). Bratislava, Institute for Public Affairs. 